Ученые записки Крымского федерального университета имени В. И. Вернадского. Филологические науки. Научный журнал. Том 6 (72). № 3. С. 147-164.

УДК 821.161.1

DOI:10.37279/2413-1679-2020-6-3-147-164

ТОЛСТОВСКИЙ ТЕКСТ В ТВОРЧЕСТВЕ А. БЛОКА

Курьянова В. В.

Таврическая академия (структурное подразделение)

ФГАОУ ВО «Крымский федеральный университет имени В. И. Вернадского»,

Симферополь, Россия

E-mail: kuryanova_v@mail.ru

В статье на материале творчества А. Блока рассматриваются элементы толстовского текста как именного сверхтекста литературы. Утверждается, что основой этого текста является миф о Л. Н. Толстом, который активно развивается на протяжении полутора столетий, но особенную актуальность получает в начале $\mathrm{XX}$ века в период популяризации духовного наследия писателя и осмысления его трагического ухода из собственного дома. Анализируется структура толстовского мифа, выявляются свойственные ему мифологемы (мифологизированные константные представления), созданные и воспроизведённые А. Блоком в соответствии с собственным поэтическим мировидением, личным отношением к творчеству и личности Л. Н. Толстого. В свете поставленной проблемы рассматриваются лирика поэта, его статьи и переписка. Акцентируется внимание на своеобразии толстовского текста в творческом наследии Блока, основанном на близости мировоззрений, сакрализации образа великого писателя, неприятии критики и профанирования образа Толстого в художественном творчестве, публицистике и мемуарах современников. В отличие от других модернистских течений символисты не ставили задачу свергать кумиров прошлого, а напротив, даже отстаивали определенную преемственность традиций, тем более это касается такого самобытного автора как Блок. Но стремление оградить Толстого от посягательств на его авторитет также дает возможность развитию биографического мифа о писателе. Поднимается вопрос об особенностях восприятия данного мифа в культуре и литературе первой трети XX века.

Ключевые слова: сверхтекст, именной текст, толстовский текст, биографический миф, миф о Л. Н. Толстом, русская литература XX века, А. Блок.

Современное литературоведение активно исследует большие текстовые структуры, относя определенный тип текстов по общности референта к топосным, событийным или именным [19]. Активно изучаются топосные тексты [см., напр.: 13; 14; 23], именные же выпадают из поля зрения литературоведов. Толстовский текст как именной сверхтекст проявляется в творчестве писателей и поэтов по-разному. Зависит это прежде всего от восприятия автором толстовского мифа, закрепленного в коллективном сознании, и от собственного мифа о Льве Толстом, созданного каждым отдельным художником.

В основу именного сверхтекста положен биографический миф, который, как правило, «работает» двухвекторно: либо на сакрализацию личности того или иного 
художника, либо на ее профанирование. При этом выбор одного из двух возможных направлений связан с мироощущением автора, особенностями его биографии, отношением к конкретной исторической фигуре в семье создателя мифа (очень важны здесь воспоминания детства, поскольку именно в детстве, отрочестве человек ищет значимые фигуры, определяющие его взросление, и такими фигурами становятся люди известные, выдающиеся), мнение его окружения, а также специфические особенности литературного течения, в рамках которого существует интерпретатор [см., напр.: 17].

Общественно-литературная ситуация начала XX века - радикальность настроений и желание обновления, формировавшееся в писательской среде, требовала новых «идолов» и поэтому не могла обойтись без свержения устоявшихся авторитетов. Под перо ниспровергателей попадали прежде всего представители творческой интеллигенции и их произведения. И, конечно, первым в этой череде писателей-классиков был Лев Толстой как авторитет несомненный и всеми признанный.

Однако фигура писателя была столь грандиозна, что именно Толстой в ситуации социально-литературного нигилизма сумел выстоять, несмотря на многочисленные попытки профанирования его образа [см., напр.: 16]. И тому, как видится, было несколько причин, но главная заключалась в том, что «великий Лев русской литературы» сам был своеобразным оппозиционером существующему общественному строю. Всевозможная критика могла касаться его спорной идеологической позиции, но никак не его безусловно высокой писательской и человеческой репутации. Поэтому представители русского символизма, не видя в нём своего непосредственного учителя, тем не менее испытывали перед Толстым несомненный пиетет.

Такое отношение хорошо просматривается в творчестве А. А. Блока, в частности в его статьях и письмах, где поддерживался сакральный миф о предшественнике.

Аристократизм, интеллигентность, образование и воспитание А. Блока способствовали уважительному отношению к гению Толстого, впрочем, как и к любому другому классику русской или европейской литературы. В статьях и 
Курьянова В. В.

переписке поэта с друзьями и близкими не только заметно личное уважение к писателю, но и духовная близость к Толстому.

По воспоминаниям А. А. Ахматовой широко известно высказывание Блока о мастере: «В тот единственный раз, когда я была у Блока, я между прочим упомянула, что поэт Бенедикт Лифшиц жалуется на то, что он, Блок, одним своим существованием мешает ему писать стихи. Блок не засмеялся, а ответил вполне серьезно: «Я понимаю это. Мне мешает писать Лев Толстой!”» [1, с. 95]. По Блоку, каждый художник при соотнесении своего творчества и своей жизни с творчеством и жизнью Толстого испытывает оторопь из-за невозможности достичь поставленных художественных и нравственных вершин, поскольку, что бы ни написал, как бы ни жил, - всё будет заведомо мелко в сравнении с гением Толстого. Таким образом, Блок одной фразой подчеркнул и величие писателя, и ощущение своего творческого родства с ним.

В статье «О драме» Блок приводит критику Шекспира Толстым, считавшим, что художественный дар английского драматурга значительно переоценён в мировой культуре. Поэт, однако, не согласившись по существу, написал: «Читая эти слова, испытываешь то же, что испытываешь, стоя на высоком холме в зимнюю вьюгу. Когда внизу, в долине, раздаются понятные нам тихие и страдательные слова о “театре мира и красоты без слез”, - здесь, на вышине, непонятно захватывает дыхание. Пронзительная вьюга так же спокойна, как слова семидесятипятилетнего мудреца, единственного гения, живущего теперь в Европе, гения без пафоса» $[10$, c. 86]. Реализуя таким образом в статье мифологему «Толстой - гений», Блок поддерживает представление, ставшее уже константным, о невозможности оценки любых суждений писателя без учета масштаба его дарования. Гениальность, по Блоку, оправдывает самую неожиданную точку зрения. Образы высокого холма, снежного ветра, с которыми нет сил спорить, дают возможность провести границу между гением и обыкновенным человеком. Блок как читатель Толстого пленен им: без «Анны Карениной», к примеру, для него жизни нет. Поэтому если что и способно повлиять на миф о гении Льва Толстого (как, впрочем, и о гениальности Шекспира), то только ситуация смены поколений, и только при том условии, что люди будущего 
«не пленятся ими, но пленятся чем-то иным, чего мы не знаем и что еще дальше и выше, чем Шекспир и Толстой» [10, с. 86]. Это утверждение любопытно тем, что Блок одновременно предрекает возможность будущего частичного разрушения мифа о Толстом-гении (чего у других авторов не найдем) и невозможность его разрушить, поскольку, кто бы ни пришел затмить Шекспира и Толстого, они всё равно останутся на завоеванной вершине.

Блоковское восхищение романами Толстого было столь велико, что он, перечитывая их очередной раз, отказывался знакомиться со второй частью книги Д. Мережковского о Достоевском и Толстом: «второй “кирпич” “Толстого и Достоевского”, думаю, ни у кого духа не хватит перечитать» («Литературные итоги 1907 года») [10, с. 111].

Влияние толстовского творчества заставило Блока сопроводить написанное в 1910 году стихотворение «На железной дороге» авторскими признаниями в «бессознательном подражании эпизоду из “Воскресения” Толстого»: «Катюша Маслова на маленькой станции видит в окне вагона Нехлюдова в бархатном кресле ярко освещенного купе первого класса» [7, с. 940]. В контексте данного утверждения очень важно слово «бессознательное», указывающее на пронизанность воображения поэта толстовскими образами и сюжетами. Событийный ряд стихотворения имеет непосредственную связь не только с «Воскресением» (как, собственно, и с «Тройкой» Н. А. Некрасова, о чем неоднократно писалось), но, как видно, и с «Анной Карениной», - связь, конечно, ассоциативную, если иметь в виду гибель Анны под поездом [см. об этом, напр.: 22]. При этом можно даже утверждать, что именно позиция Толстого в романе «Анна Каренина» (а не в «Воскресении» - по Блоку, «завещании уходящего столетия новому») оказала влияние на идейноэмоциональный фон стихотворения. Объяснение поэтом причин гибели героини («Любовью, грязью иль колесами / Она раздавлена...») более соответствует трагической сложности чувств Анны, подчиненных всепоглощающей любви к Вронскому, но никак не бегству Нехлюдова от Катюши Масловой, в чем отчетливо прочитывается социальный конфликт. Блок оставляет самому читателю (интерпретатору) право решать, что именно погубило героиню, замечая при этом, что 
Курьянова В. В.

- «всё больно»: клубок противоречий настолько запутан, что нет возможности говорить о конкретной (социальной ли, бытовой ли) причине происшедшего. Переплетение толстовских образов, деталей, мотивов в одном этом стихотворении наводит на мысль, что Блок, погруженный в произведения Толстого, невольно оказывался в их власти, что продуцировало богатый ассоциативный ряд.

Образ самого Толстого в лирике Блока возникает лишь однажды, да и то в черновом варианте стихотворения «О, как смеялись вы над нами...». Изначально этот фрагмент должен был стать главкой поэмы «Возмездие», но затем - с заметной корректировкой, в том числе и с исключением упоминания о Толстом, - текст был напечатан Блоком отдельным стихотворением в журнале «Радуга» (1915 год) в цикле «Ямбы». В черновом варианте строки с упоминанием Толстого вписывались в следующий контекст:

Пусть будет прост и скуден храм,

Где небо кроют мглою бесы,

Где слышен хохот желтой прессы,

Жаргон газет и визг реклам,

Где под личиной провокаций

Скрывается больной цинизм,

Где торжествует нигилизм -

Бесполый спутник «стилизаций»,

Где «Новым Временем» смердит,

И хамство с каждым годом - пуще,

Где полновластны, вездесущи

Лишь офицер, жандарм и жид,

Где память вечную Толстого

Стремится омрачить жена... [7, с. 280-281]

Рисуя живую картинку современности, поэт фиксирует ситуацию, ставшую уже устойчивой мифологемой биографического мифа о писателе: взаимоотношение 
Л.Н. Толстого с женой. Это мифологизированное константное представление (термин С. О. Курьянова [15, с. 30]) носит профанный характер, поскольку сложный выбор между интересами семьи и отречением от них окончательно Толстым сделан не был. Сомнения писателя, в которых многие видели лицемерие, подвергались современниками осмеянию. Решение писателя отказаться от имения, доходов от публикаций своих произведений было резко негативно воспринято Софьей Андреевной Толстой, из-за чего конфликты, недоверие и недовольство друг другом с упоением смаковалось общественностью в силу публичности жизни Толстых. Уход из дома и смерть писателя породили еще большее количество слухов, домыслов и легенд, ставших компонентами биографического мифа о Льве Толстом [4].

С. А. Толстая чувствовала свою долю вины в создании атмосферы конфликтности в семье и косвенно в этом признавалась как до ухода, так и после смерти мужа. Д. П. Маковицкий, врач и последний спутник писателя, незадолго до их бегства так описал в своих дневниках атмосферу, царившую в доме Толстых: «Татьяна Львовна, Андрей, Михаил и В. Философов были усталые и встревоженные, озабоченные положением и отца, и матери. Успокаивали мать, но нервно, с укорами. Софья Андреевна выставляла причиной свое нездоровье..., а потом созналась: “Я пересолила"》 $[21$, с. 420]. Она боялась остаться для последующих поколений единственной причиной произошедшего, поскольку понимала, что жену как самого родного и близкого человека будут винить в первую очередь. Поэтому, пытаясь оправдаться, давала комментарии многочисленным журналистам, дежурившим у смертного одра Толстого и множившим информационный материал, повлиявший на содержание мифа об уходе писателя (см., напр., «Астаповские телеграммы» [25]).

По воспоминаниям тетки А. Блока М. А. Бекетовой: «уход Толстого волновал и радовал Ал.<ександра > Ал.<ександровича.> По поводу этого события и всех его последствий он даже читал газеты, что вообще не входило в обиход его жизни и случалось лишь периодически» [6, с. 141].

Мотив ухода занимал также и авторское сознание поэта (см., напр.: «Безвременье», 1906; «Девушка розовой калитки и муравьиный царь», 1906; «Песня Судьбы», 1908; «Соловьиный сад», 1914; иные стихотворения), приобретая под его 
Курьянова В. В.

пером сакральный смысл. Однако десакрализирующую сторону той же мифологемы Блок остро чувствовал. В речи на смерть В. Соловьева «Рыцарь-монах» поэт рассуждает о земной жизни выдающейся личности, и в соответствии с поводом написания статьи оценивает кончину творца: нужно ли рассуждать об уходе, когда свет жизни был так значителен, - «многие готовы сто раз твердить одно и то же о гениальности "Войны и мира", только бы замолчать успение и конец самого Толстого» [11, с. 137].

О том, что Блок, выступая вначале на стороне обвинителей Софьи Андреевны, уходил в стихотворении (главке поэмы) от десакрализирующей тенденции биографического мифа о Толстом, свидетельствует работа над текстом. Первоначальный вариант («И где священный прах Толстого / Стремится омрачить жена» [7, с. 281]) не устраивает поэта. «Прах Толстого» есть нечто материальное. По Блоку же не на материальном, а на духовном начале описания гения должны сделать акцент. И поэт меняет словосочетание «священный прах» на «память вечную». Но в конце концов убирает и эти строки, заметив в черновой рукописи: «гадость» $[7$, c. 693]. Таким образом поэт отказывается от участия в умножении газетножурнальных сплетен о кончине Толстого, а тем самым и от участия в создании профанного биографического мифа о нём.

Смысловая концовка стихотворения вполне соответствует мировоззренческой корректуре Блока, не желающего опошлить образ великого художника:

Но помни Тютчева заветы:

Молчи, скрывайся и таи

И чувства и мечты свои... [7, с. 61]

Цитируя поэта-философа, Блок как бы призывает вдову Толстого не выставлять напоказ свои мысли и чувства, а себя - отказаться от досужих суждений о Софье Андреевне, миф о которой в разных интерпретациях живет в культуре и литературе XX - начала XXI веков. 
Поэма «Возмездие», из которой был исключен данный отрывок, писалась Блоком тяжело, долго, о чем свидетельствует его переписка с матерью, друзьями, и, как известно, так и не была завершена. В черновиках третью главу поэмы открывает предисловие, созданное в 1910 году: «1910 год - это смерть Коммиссаржевской (так у Блока. - В. К.), смерть Врубеля и смерть Толстого. С Коммиссаржевской умерла лирическая нота на сцене; с Врубелем - громадный личный мир художника, безумное упорство, ненасытность исканий - вплоть до помешательства. С Толстым умерла человеческая нежность - мудрая человечность» [9, с. 48]. Восприятие Блоком Толстого не строится только на стереотипах, даже понятные мифологемы «Толстой - гений», «Опрощение Толстого» поэт снабжает очень яркими, уникальными эпитетами. Для Блока Толстой нежен по-человечески, человечен как истинный мудрец, т.е. недосягаемая вершина и одновременно - близкий человек, смерть которого переживается очень болезненно.

Во всех остальных случаях мы находим у поэта различные элементы канонизирующе-сакрализирующего мифа о Льве Толстом. Так, например, в одном из ранних стихотворений Блока - «На Вечере в честь Л. Толстого» (1898) - отчетливо прочитывается мифологема «Толстой - кумир современников». Причем преподносится она «мимоходом», в качестве уже вполне сформировавшейся в сознании поэта. Лирический герой произведения, присутствуя на празднике, посвященном 70-летию Л. Н. Толстого, оказывается среди собратьев по перу - в «толпе родной по вдохновенью». Но волнуют его не окружающие люди, не само событие, а спутница, уста которой дышат «холодом могилы», его безнадежная любовь. И ему остаётся, глядя на то, как восторженно публика встречает Толстого, надеяться лишь на грядущий поэтический успех, который, быть может, растопит холодное сердце любимой:

И мне хотелось блеском славы

Зажечь любовь в Тебе на миг,

Как этот старец величавый

Себя кумиром здесь воздвиг! [8, с. 15] 
Курьянова В. В.

Мифема «старец величавый», соотносится с представлениями о святости, мудрости (ср. у В. Г. Бенедиктова: «В ризе святости и славы, / Опоясан стариной, / Старец Киев предо мной / Возблистал золотоглавый. / Здравствуй, старещ величавый!» [6, с. 119]; курсивом выделено нами. - В. К.).

В посвященном Вл. Пясту стихотворении «Май жестокий с белыми ночами!..» (1908), где реализуется характерное для Блока противопоставление мечты и действительности, в самом конце как утверждение необходимости деяний, возникает образ человека, свободного от ненужных страстей, обретшего свое предназначение в труде. По Блоку, наслаждение жизнью важно, поэтому «хорошо в лугу широким кругом / В хороводе пламенном пройти, / Пить вино, смеяться с милым другом / И венки узорные плести...». Но эпикурейское восприятие жизни объяснимо не даёт возможности увидеть ее смысл, который проявляется в долженствующем, а не в сиюминутно желаемом. При этом, подчиняясь долгу, человек вовсе не теряет возможности наслаждаться жизнью, а придаёт наслаждению нравственную значимость: «Но достойней за тяжелым плугом / В свежих росах поутру идти!». Образная структура стихотворения содержит аллюзию на фигуру Л. Н. Толстого. То, что Блок имеет в виду именно Толстого, понятно из его статьи «Солнце над Россией» (1908), написанной к восьмидесятилетию писателя: «Пока Толстой жив, идет по борозде за плугом, за своей белой лошадкой, - еще росисто утро, свежо, нестрашно, упыри дремлют, и - слава Богу. Толстой идет - ведь это солнце идет» [11, с. 55].

Блок, как видим, не свободен в своих суждениях от образов И. Е Репина, одного из самых кропотливых создателей биографического мифа о Толстом, и конкретно от художественной концепции его картины «Пахарь. Л. Н. Толстой на пашне» (1887). Картина эта была написана после посещения Репиным Ясной Поляны, где он вместе с Толстым оказался на пашне крестьянской вдовы, которой писатель помогал по хозяйству. Рисуя фигуру Толстого-пахаря, художник, как и проезжавшие мимо крестьяне, с иронией отнёсся к «великому оратаюшке», но быстро изменил к ситуации своё отношение, когда сам взял в руки плуг и испробовал тяжёлый труд землепашца. Завершающим аккордом его воспоминаний об этом дне станут слова о Толстом: «Вот он, Микула Селянинович, непобедимый никакими храбрецами в 
доспехах. Микула вооружен только вот таким терпением и привычкой к труду» $[18$, с. 484-485]. Мифологему «Толстой-пахарь» Блок использует в стихотворении и статье, подчёркивая величие русского писателя-моралиста.

В названии своей статьи Блок метафорически определяет Толстого «солнцем над Россией», и дает понять, что, если это солнце закатится, «уйдёт последний гений» [11, с. 54] (Любопытно в качестве сравнения стихотворение, написанное А. Ахматовой после похорон А. Блока: «Наше солнце, в муке погасшее»).

Среди тех, кто, по мнению Блока, стремился погасить «солнце» русской литературы, был обер-прокурор Святейшего синода К. П. Победоносцев, чей образ поэт целенаправленно демонизировал. Помимо статьи, мрачная фигура оберпрокурора появляется в поэме «Возмездие»:

В те годы дальние, глухие,

В сердцах царили сон и мгла:

Победоносцев над Россией

Простёр совиные крыла,

И не было ни дня, ни ночи

А только - тень огромных крыл;

Он дивным кругом очертил

Россию, заглянув ей в очи

Стеклянным взором колдуна [9, с. 45].

Напомним, Л. Н. Толстой впервые обратился к Победоносцеву в 1881 году с просьбой передать прошение Александру III о помиловании убийц его отца императора Александра II. Но тот не только не передал прошения, но настоятельно призывал к непременной смертной казни обвиняемых.

В данном случае мифологема «о непротивлении злу насилием» возникает на оппозиции биографического мифа о Льве Толстом и мифа о Победоносцеве государственном деятеле, который настаивал на ветхозаветном ответе «око за око». 
Курьянова В. В.

Исповедуя этот принцип, Победоносцев сыграл активную роль и в создании «Определения Святейшего Синода» о графе Льве Толстом [24, с. 47].

«Старый упырь теперь в могиле», - писал Блок в 1908 году (К. П. Победоносцев умер в 1907 году), но «тень <его> наложила запрет на радость» [11, с. 53], на широкомасштабное празднование юбилея Толстого. Поэт ощущает мрачное дыхание реакции - «знакомый аккомпанемент административных распоряжений и губернаторско-уряднических запрещений шевелиться, говорить и радоваться по поводу юбилея Льва Толстого», поскольку за всеми «глядит мертвое и зоркое око, подземный, могильный глаз упыря» [11, с. 53-55]. Но не так страшно все, утверждает поэт, пока гений жив. Страшнее будет, когда его не станет. Мифологема о живом гении перекликается с целым рядом газетных заметок о юбилее писателя: «Когда в литературе есть Толстой, то легко и приятно быть литератором. Даже сознавать, что ничего не сделал и не делаю, - не так страшно, так как Толстой делает за всех. Его деятельность служит оправданием всех упований, какие на литературу возлагаются»; «Жив Толстой - воплощение русской совести и правды, прекрасное даже в своих ошибках и противоречиях <..>. Велика радость и велико счастье жить с Толстым. Страшно жить без Толстого» [цит. по: 20, с. 324].

Мифологему «Толстой и толстовство» Блок использует в статье «Литературные итоги 1907 года» (1907) [10, с. 111-122], где говоря о толстовцах-литераторах, исповедующих идеи великого моралиста, отмечает, что как художники они оказываются чрезвычайно слабыми в литературном отношении и выступают скорее в качестве сектантов от литературы.

Мифологема «Толстой-гений» также реализуется Блоком в оппозиции гению Д. И. Менделеева, поэт видит два пути развития России, противоречащие друг другу: «...трагедия (имеется в виду размежевание интеллигенции и народа. - B. K.) за последнее время выразилась всего резче в непримиримости двух начал менделеевского и толстовского» (статья «Народ и интеллигенция») [11, с. 74]. Путь Менделеева - это вера в науку (идеи Д. И. Менделеева и А. Н. Бекетова о развитии науки и производительных сил России отозвались в ряде стихотворений Блока «Новая Америка» и др.), развитие человечества, путь Толстого - религиозная вера. 
Эти два пути, не отрицая друг друга, определяющими имеют во многом противоположные начала. Восхищение Блока гением Менделеева равновелико восхищению гением Толстого. «Твой папа [Д. И. Менделеев], - пишет он Л. Д. Менделеевой 15 мая 1903 года, - вот какой: он давно все знает, что бывает на свете. Во все проник. Не укрывается от него ничего. Его знание самое полное. Оно происходит от гениальности, у простых людей такого не бывает. У него нет никаких “убеждений” (консерватизм, либерализм, и т. д.). У него есть все» [1, с. 130]. Воспитание и образ жизни Менделеева не дает возможности записать его в атеисты, однако единственная «тройка» в университете, портящая средний балл диплома, была у него по Закону Божьему. Понимание Толстым науки, конечно, не сводилось к ее отрицанию, но для писателя наука все же была прежде всего образованием, давала возможность повысить социальный статус. Научное знание для Толстого определяющим в жизни не могло стать никогда: «Не могло быть этого, и нет этого: настоящая наука та, которую необходимо знать каждому, доступна и понятна каждому, потому что вся эта наука в главной основе своей, из которой каждый может вывести ее приложения к частным случаям, вся она сводится к тому, чтобы любить Бога и ближнего, как говорил Христос» («О науке. Ответ крестьянину», 1910) [26, c. 137]. В этой статье Толстой приводит пример директрисы гимназии Акулины Тарасовны, которая по счастливому для нее случаю получила образование и изменила свое социальное и культурное положение: вместо битой дворовой Акульки «теперь любезная, умная директриса, белыми руками сдающая карты, остроумно шутящая о персидских делах со старинным приятелем и сыном ее воспитателя и предпочитающая чай с лимоном, а не со сливками» [26, с. 136]. Но даже образование, по Толстому, это не истинная, а ложная наука: только близость к народу, духовное совершенствование будет наукой подлинной.

И Толстой, и Менделеев как интеллигенты, искренне служащие благу человечества, в понимании Блока близки народу. «Но решить, чьи взгляды выражают подлинные интересы народа, Блок не может: для него народны и Менделеев, и Толстой» [22, с. 131]. Пути ищущих истину великих людей расходятся, в этом Блок среди прочего видит трагедию отрыва интеллигенции от народа. 


\section{ВЫВОДЫ}

Александр Блок - поэт рефлексирующий, сомневающийся, призывающий «слушать музыку революции» и одновременно сокрушающийся о сожженной крестьянами библиотеке в Шахматово, желающий изменений в общественной и политической жизни родины, но не переживший этих изменений. Несомненно, ему была близка сложная и противоречивая личность Л. Н. Толстого. Он восхищался художественным гением Толстого и в своем творчестве интерпретировал его сюжеты и идеи. Преклонение пред классиком порождало желание монументализировать его фигуру и очистить его биографию от всевозможных искажений. Но и то, и другое лишь подпитывает складывающийся в это время биографический миф о Толстом. Важными мифопорождающими факторами для поэта становятся гениальность Толстого, величие ухода писателя, взгляд на него как кумира современности, как идеолога опрощения, как основателя толстовства. Все эти константные представления в творчестве А. Блока, наряду с произведениями иных авторов, так или иначе способствовали формированию толстовского текста в русской литературе начала XX века.

\section{Список литературы}

1. Александр Блок в воспоминаниях современников: в 2 т. Т. 2 [Текст]. - М. : Художественная литература, 1980.

2. Александр Блок. Письма к жене [Текст] / под ред. В. Г. Базанова, Д. Д. Благого, А. Н Дубовикова， И. С. Зильберштейн， С. А. Макашина， К. Д. Муратова, Л. И Тимофеева, Н. А. Трифонова, М. Б. Храпченко, В. Р. Щербины (глав. ред.). М. : Издательство «Наука», 1978 (Литературное наследство, Т. 89).

3. Ахматова, А. Собрание сочинений: в 6 т. Т. 1 [Текст] / А. Ахматова. - М. : ЭллисЛак, 1998.

4. Басинский, П. В. Лев Толстой: бегство из рая [Текст] / П. В. Басинский. - М. : АСТ ; АСТРЕЛЬ, 2011.

5. Бекетова, М. А. Александр Блок: Биографический очерк. 2-е изд. [Текст] / М. А. Бекетова. - Ленинград: АCADEMIA, 1930. 
6. Бенедиктов, В. Г. Стихотворения [Текст] / В. Г. Бенедиктов. - М. : Советская Россия, 1991.

7. Блок, А. Полное собрание сочинений и писем : в 20 т. Т. 3 [Текст] / А. Блок. - М. : Наука, 1997.

8. Блок, А. Полное собрание сочинений и писем : в 20 т. Т. 4 [Текст] / А. Блок. - М. : Наука, 1999.

9. Блок, А. Полное собрание сочинений и писем : в 20 т. Т. 5 [Текст] / А. Блок. - М. : Наука, 1999.

10. Блок, А. Полное собрание сочинений и писем : в 20 т. Т. 7 [Текст] / А. Блок. - М. : Наука, 2003.

11. Блок, А. Полное собрание сочинений и писем : в 20 т. Т. 8 [Текст] / А. Блок. - М. : Наука, 2010.

12. Блок, А. Собрание сочинений : в 8 т. Т. 8 [Текст] / А. Блок. - М. ; Л. : Художественная литература, 1963.

13. Иванова, Н. П. Оппозиция «мечта - реальность» в крымском тексте Брюсова В. Я. [Текст] / Н. П. Иванова // Ученые записки Крымского федерального университета имени В. И. Вернадского. Филологические науки. - 2019. - Т. 5 (71). - № 1. - С. 60-69.

14. Курьянов, С. О. Миф о Крыме как о восточной мусульманской стране в повестях азовского цикла (XVII век) [Текст] / С. О. Курьянов // Ученые записки Крымского федерального университета имени В. И. Вернадского. Филологические науки. 2015. - T. 1 (67). - № 4. - C. 53-61.

15. Курьянов, С. О. Тайный ключ русской литературы: формирование и становление крымского текста в русской литературе X-XIX веков : монография [Текст] / С. О. Курьянов. - М. : ИНФРА-М, 2019.

16. Курьянова, В.В. Толстовский миф в творчестве В.В. Маяковского [Текст] / В. В. Курьянова // Litera. - 2018. - № 4. - С. 152-167.

17. Курьянова, В.В. Толстовский текст и миф о Л. Н. Толстом в творчестве И. Ильфа и Е. Петрова [Текст] / В. В. Курьянова // Научный диалог. - 2019. - № 1. - С. 179194. 
Курьянова В. В.

18. Л. Н. Толстой в воспоминаниях современников: в 2 т. Т. 1 [Текст]. - М. : Художественная литература, 1978.

19. Лошаков, А. Г., Шушарин, И. А. Пролегомены к концепции Пушкинского текста русской литературы [Текст] / А. Г. Лошаков, И. А. Шушарин // Вестник Северного (Арктического) федерального университета. Серия «Гуманитарные и социальные науки». - 2016. - №5. - С. 117-127.

20. Магомедова, Д. М. Примечания [Текст] / Д. М. Магомедова // Блок А. Полное собрание сочинений и писем: в 20 т. Т. 8. - М. : Наука, 2010.

21. Маковицкий, Д. П. У Толстого. 1904-1910 [Текст] / Д. П. Маковицкий // «Яснополянские записки»: в 5 кн. Кн. 4. 1909 (июль-декабрь). 1910. - М. : Издательство «Наука», 1979-1981 (Литературное наследство. Т. 90).

22. Минц, 3. Г. Блок и Л. Н. Толстой [Текст] / 3. Минц // Минц 3. Г. Александр Блок и русские писатели. - Санкт-Петербург : ИСКУССТВО-СПБ, 2000.

23. Новикова, М. А. Сверхтексты в литературе: жанры и циклы (к постановке проблемы) [Текст] / М. А. Новикова // Ученые записки Крымского федерального университета имени В. И. Вернадского. Филологические науки. - 2018. - Т. 4 (70). - № 4. - С. 72-84.

24. Определение святейшего синода от 20-22 февраля 1901 года, с посланием верным чадам православныя грекороссийския церкви о графе Льве Толстом [Текст] // «Церковные ведомости, издаваемые при святейшем правительствующем синоде». - 24 февраля 1901. - № 8. - С. 45-47.

25. Смерть Толстого. По новым материалам [Текст] / вступ. ст. В. И. Невского. - М. : Издание Публичной библиотеки СССР им. В.И. Ленина, 1929.

26. Толстой, Л. Н. Полное собрание сочинений: в 90 т. Т. 38. Произведения 1909-1910 [Текст] / Л. Н. Толстой / под общ. ред. В. Г. Черткова. - М. : Художественная литература, 1936. 


\section{References}

1. Aleksandr Blok v Vospominaniyakh Sovremennikov: v 2 Tomakh. Tom 2 [Alexander Blok in the Memoirs of Contemporaries]. In 2 Vols. Vol. 2. Moscow: Khudozhestvennaya Literatura Publ., 1980.

2. Aleksandr Blok. Pis'ma k Zhene [Letters to Wife]. Ed. by V. G. Bazanov, D. D. Blagoi, A. N. Dubovikov, I. S. Zil'bershtein, S. A. Makashin, K. D. Muratov, L. I Timofeev, N. A. Trifonov, M. B. Khrapchenko, V. R. Shcherbina. Moscow: Nauka Publ., 1978.

3. Akhmatova A. Sobranie Sochinenii v 6 Tomakh. [Collected Works] In 6 Vols. Vol 1. Moscow: Ellis-Lak Publ., 1998.

4. Basinskii P. V. Lev Tolstoi: Begstvo iz Raya [Leo Tolstoy. Escape from Paradise]. Moscow: AST; ASTREL Publ., 2011.

5. Beketova M. A. Aleksandr Blok: Biograficheskii Ocherk [Alexander Blok. Biographical Sketch]. Leningrad: ACADEMIA Publ., 1930.

6. Benediktov V. G. Stikhotvoreniya [Poems]. Moscow: Sovetskaya Rossiya Publ., 1991.

7. Blok A. Polnoe Sobranie Sochinenii i Pisem: v 20 Tomakh. Tom 3 [Complete Works and Letters]. In 20 Vols. Moscow: Nauka Publ., 1997. Vol. 3.

8. Blok A. Polnoe Sobranie Sochinenii i Pisem: v 20 Tomakh. Tom 4 [Complete Works and Letters]. In 20 Vols. Moscow: Nauka Publ., 1999. Vol. 4.

9. Blok A. Polnoe Sobranie Sochinenii i Pisem: v 20 Tomakh. Tom 5 [Complete Works and Letters]. In 20 Vols. Moscow: Nauka Publ., 1999. Vol. 5.

10. Blok A. Polnoe Sobranie Sochinenii i Pisem: v 20 Tomakh. Tom 7 [Complete Works and Letters]. In 20 Vols. Vol. 7. Moscow: Nauka Publ., 2003.

11. Blok A. Polnoe Sobranie Sochinenii i Pisem: v 20 Tomakh. Tom 8 [Complete Works and Letters]. In 20 Vols. Vol. 8. Moscow: Nauka Publ., 2010.

12. Blok A. Sobranie Sochinenii: v 8 Tomakh. Tom 8 [Collected works]. In 8 Vols. Vol. 8. Moscow: Leningrad, 1963.

13. Ivanova N. P. Oppozitsiya «mechta - real'nost'« v krymskom tekste Bryusova V. YA. [Opposition «dream - reality» in the Crimean text of Bryusov V. Ya.]. Uchenyye zapiski 
Krymskogo federal'nogo universiteta imeni V. I. Vernadskogo. Filologicheskiye nauki. 2019. V. 5 (71). № 1. pp. 60-69.

14. Kur'yanov S. O. Mif o Kryme kak o vostochnoy musul'manskoy strane v povestyakh azovskogo tsikla (XVII vek) [The myth of the crimea as the eastern muslim country in stories of azov cycle (XVII century)]. Uchenyye zapiski Krymskogo federal'nogo universiteta imeni V. I. Vernadskogo. Filologicheskiye nauki. 2015. V. 1 (67). № 4. pp. 53-61.

15. Kur'yanov S. O. Tainyi Klyuch Russkoi Literatury: Formirovanie i Stanovlenie Krymskogo Teksta v Russkoi Literature X-XIX Vekov: Monografiya [The Secret Key of Russian Literature. Formation and Creation of the Crimean Text in Russian Literature of the $10-19^{\text {th }}$ Centuries: Monograph]. Moscow: INFRA-M Publ., 2019. 308 p.

16. Kur'yanova V.V. Tolstovskii Mif v Tvorchestve V. V. Mayakovskogo [Tolstoyan Myth in the Work of V.V. Mayakovsky]. Saint Petersburg: Litera, 2018, № 4, pp. 152-167.

17. Kur'yanova V.V. Tolstovskii Tekst i Mifo L. N. Tolstom v Tvorchestve I. Il'fa i E. Petrova [Tolstoyan Text and Myth of L. N. Tolstoy in Works by I. Ilf and. E. Petrov]. Nauchnyi Dialog, 2019, №1, pp. 179-194.

18. L. N. Tolstoi v Vospominaniyakh Sovremennikov: $v 2$ Tomakh [L. N. Tolstoy in the Memoirs of Contemporaries]. In 2 Vols. Vol. 1. Moscow, 1978.

19. Loshakov A. G., Shusharin I. A. Prolegomeny k Kontseptsii Pushkinskogo Teksta Russkoi Literatury [Prolegomes to the Concept of the Pushkin Text of Russian Literature]. Vestnik Severnogo (Arkticheskogo) Federal'nogo Universiteta. Seriia Gumanitarnye i Sotsial'nye Nauki, №5, 2016, pp. 117-127.

20. Magomedova D. M. Primechaniya. [Notes]. Blok A. Polnoe Sobranie Sochinenii $i$ Pisem: v 20 Tomakh. Vol. 8. Moscow: Nauka Publ., 2010.

21. Makovitskii D. P. U Tolstogo. 1904-1910 [Tolstoy. 1904-1910]. Yasnopolianskie Zapiski: v 5 Knigakh. Kniga 4. 1909 (Iyul'-Dekabr'). 1910. Moscow: Nauka Publ, 19791981 (Literaturnoe Nasledstvo. Vol. 90).

22. Mints Z. G. Blok i L.N. Tolstoi. [Block and L. N. Tolstoy]. Aleksandr Blok i Russkie Pisateli. Saint Petersburg: ISKUSSTVO-SPB Publ., 2000. 
23. Novikova M. A. Sverkhteksty $v$ literature: zhanry i tsikly (k postanovke problemy) [Supertexts in literature: genres and cycles (to the problem statement)]. Uchenyye zapiski Krymskogo federal'nogo universiteta imeni V. I. Vernadskogo. Filologicheskiye nauki. 2018. V. 4 (70). № 4. pp. 72-84.

24. Opredelenie Sviateishego Sinoda ot 20-22 Fevralya 1901 Goda, s Poslaniem Vernym Chadam Pravoslavnyya Grekorossiiskiya Tserkvi o Grafe L've Tolstom [Definition of the Holy Synod of February 20-22, 1901, with a Message to the Faithful Children of the Orthodox Greek-Russian Church on Count Leo Tolstoy]. Tserkovnye Vedomosti, Izdavaemye pri Sviateishem Pravitel'stvuiushchem Sinode, February 24, 1901, № 8, pp. 45-47.

25. Smert' Tolstogo. Po Novym Materialam [The Death of Tolstoy. According to New Materials]. Moscow. 1929.

26. Tolstoi L. N. Polnoe Sobranie Sochinenii: v 90 Tomakh. Tom 30. Proizvedeniya 19091910 [Complete Works. In 90 Vols. Vol. 30. 1909-1910 Works]. Moscow: Khudozhestvennaya Literatura, 1936.

\title{
TOLSTOVSKY TEXT IN WORKS BY A. BLOK
}

\author{
Valeria V. Kuryanova
}

\begin{abstract}
The article, based on the material of A. Blok's work, examines the elements of the Tolstoyan text as a nominal supertext of literature. It is argued that the basis of this text is the myth of L.N. Tolstoy, which has been actively developing for a century and a half until today, but at the beginning of the 20th century, when Tolstoy's tragic departure from his own home became popular, it became especially relevant. The structure of the Tolstoyan myth is analyzed, the mythologies associated with it (mythologized constant representations) created and reproduced by A. Blok in accordance with his own poetic worldview, personal attitude to the work and personality of L.N. Tolstoy. In light of the problem posed, the poet's lyrics, his articles, and correspondence are examined. Attention is focused on the originality of the Tolstoy text in the creative heritage of Blok, based on the proximity of worldviews, the sacralization of the image of the great writer, rejection of criticism and profanation of the image of Tolstoy in contemporary art, journalism and memoirs. Unlike other modernist movements, the Symbolists did not set the task of overthrowing the idols of the past, but on the contrary, they even defended a certain continuity of traditions, all the more so with such an original author as Blok. But the desire to protect Tolstoy from attacks on his authority also makes it possible to develop a biographical myth about the writer. The question is raised about the features of the perception of this myth in the culture and literature of the first third of the XX century.

Keywords: supertext, Tolstoyan text, nominal text, biographical myth, myth of L. N. Tolstoy, Russian literature of the 20th century, A. Blok.
\end{abstract}

